\title{
Refashioning the Ethiopian monarchy in the twentieth century: an intellectual history
}

[Global Intellectual History, forthcoming - special issue on "The Modern Invention of Dynasty"]

\author{
Sara Marzagora \\ https://orcid.org/0000-0003-3989-3080 \\ SOAS University of London \\ sm137@soas.ac.uk
}

\begin{abstract}
This article traces the shift in the Ethiopian monarchical ideology from lineage as symbolic Christian filiation to dynasty as a political genealogy of sovereign power. From the end of the nineteenth century, and more prominently under Haylä Səllase, Ethiopian state sources started qualifying the Ethiopian ruling dynasty as 'unbroken' in history. A record of 'uninterrupted' power allowed the Ethiopian government to politically appropriate past glories and claim them as 'ours', thus compensating for the political weakness of the present with the political greatness of the past. The ideological rebranding of the Ethiopian monarchy in the 1930s brought Ethiopia closer to Japan, and the 'eternalist clause' of the Meiji constitution offered a powerful model of how to recodify dynasty in modern legal terms. An intellectual history of dynasty in the Ethiopian context sees the concept simultaneously associated with both hegemonic and counter-hegemonic political projects. The narratives of continuity enabled by the dynastisation of history were successful in invigorating the pro-Ethiopian front during the Italian occupation of Ethiopia (1936-1941), but served at the same time to reinforce domestic mechanisms of class, political and cultural domination.
\end{abstract}

Keywords: dynastic nationalism, Ethiopian history, Ethiopian nationalism, Ethiopian monarchy, Solomonic dynasty, Solomonic myth

\section{Religious lineage to political dynasty}

The kings of the Christian highlands of Northeast Africa, we are told in countless historical works, ruled for centuries according to the prescriptions of a 'national epic', the Kəbrä Nägäst ('The Glory of Kings'). If we read Ethiopian history books published in the 1950s, 1960s and all the way to the present, this is what we generally learn: the Kəbrä Nägäst was compiled in its definitive form in the fourteenth century to legitimise the coming to power in Ethiopia of a new family line. Yəkunno Amlak took power in 1270, ousting the last of the Zagwe kings, and the violent power reshuffle required a 
validating ideology. For centuries the legend of the Queen of Sheba had circulated in different versions and in various cultural traditions both orally and in writing. The authors of the Kabrä Nägäst drew from this tradition to create a ruling ideology so powerful and influential, twentieth century historians argue, that all Yəkunno Amlak's descendants had to abide by it. Such ideology hinged on divine election. Ethiopia's covenant with God was established through the actions of the son of King Solomon and of the Queen of Sheba, later known by the name Mənilək I. After growing up in his mother's kingdom, Mənilək visited his father in Jerusalem, and on the way back he transferred the Ark of the Covenant to the city of Aksum in his mother's kingdom. When the Ark arrived in Aksum, people converted to the new religion, the Queen of Sheba abdicated in favour of her son, and with Mənilək's enthronement a new dynastic line of 'Solomonic' kings was founded. 'No one except the male seed of David, the son of Solomon the King', asserts the Queen in chapter 87 of the Kabrä Nägäst, 'shall ever reign over Ethiopia'. ${ }^{1}$ Yəkunno Amlak claimed Solomonic ancestry, and thanks to the Kəbrä Nägäst his ascension could now be framed as the restoration of Ethiopia's legitimate rulers over the Zagwe usurpers. All subsequent Ethiopian emperors belonged to the same line and could only rule if they demonstrated Solomonic ancestry. The ideology of the Kəbrä Nägäst is old, we are repeatedly told, and permeates every detail of the political culture of the Ethiopian empire. Donald Levine defines it as a 'national epic' on the grounds that it 'advances a firm conception of Ethiopian national character and purpose'. ${ }^{2}$ There is 'so much more at stake [in it] than the fortunes of a particular dynasty', he concludes. ${ }^{3}$

In this interpretation, 'dynasty' is taken for granted as a self-evident political category. And yet, if we historicise the term, we see that the way in which we understand 'dynasty' nowadays does not neatly correspond to medieval and modern understandings of royal lineage. In the medieval and modern history of the Ethiopian empire, I argue in this article, lineage indicated a symbolic religious ancestry. Lineage was an important pre-condition of monarchical legitimacy, but other qualities were required of a ruler, such as military leadership and a commitment to Christian values. Claiming Solomonic descent was a way for rulers to demonstrate their religious credentials and divine election. Succession did happen for centuries through the male line as prescribed by the Kabrä Nägäst, but the myth narrated by the Kabrä Nägäst did not seem to have occupied the ideological prominence that twentieth century sources credit it with. The medieval and modern history of Solomonic dynasty, in other words, did not go hand in hand with the history of the Solomonic myth. The Kabrä Nägäst started gaining importance in the late nineteenth century, in a context of political and economic globalisation in which sovereignty was increasingly predicated on external recognition. In 1896 Emperor Mənilək II defeated an Italian invasion attempt at Adwa, and Ethiopia entered the twentieth century as a formally independent polity, but colonialism remained a looming threat. To the Ethiopian ruling class, the Solomonic myth offered room to push back against ideologies of European civilizational superiority. Ethiopian elites started qualifying the Solomonic dynasty as 'unbroken' and 'uninterrupted', a characterisation that allowed them to ideologically appropriate as 'ours' the empire's ancient glories and civilisational achievements. 
The article traces such shift from lineage as symbolic Christian filiation to dynasty as a political genealogy of sovereign power. The dynastisation of the Ethiopian monarchy, I argue, was intended as an anti-colonial weapon, but also carried its own set of ambiguities. On the one hand, the new dynastical nationalism increased Ethiopia's civilisational standing in the eyes of at least some segments of European civil society, prompting British activists in London to vociferously campaign against Mussolini's 1935 invasion. Even more significantly, the narratives of Ethiopian dynastical antiquity offered an empowering reference for black and Pan-Africanist activists fighting against the racist erasure of African people's history. And yet, dynasty was also a tool for authoritarian rule at home, where it was used to legitimise the ruling rights of the Christian Amharic-speaking population over the non-Christian inhabitants of the Ethiopian lowland peripheries and semi-peripheries. An intellectual and conceptual history of 'dynasty' in Ethiopia is inseparable from these ideological and political struggles over sovereignty, recognition, and emancipation. This article charts the global trajectories of these struggles from Tokyo to Addis Abäba, from Addis Abäba to London, and from London to New York, showing how Ethiopian dynastical nationalism was transnationally renegotiated for a good part of the twentieth century.

\section{The Solomonic dynasty vs. the Solomonic myth}

In much twentieth century scholarship, the Kabrä Nägäst is hailed as the cornerstone of Ethiopia's monarchical ideology. But if instead of reading twentieth century scholarship we go back to earlier sources, the picture is much more fluid. The Kabrä Nägäst is regularly referenced in arguments that stress the singularity and uniqueness of the Ethiopian empire, but both the notion of Israelite descent and the idea that the Ark of the Covenant had reached Ethiopia predate the composition of the Kabrä Nägäst. Claims of Israelite descent were a frequent phenomenon in the monarchies of the Middle East and Northeast Africa in ancient and medieval times. This is in turn 'obviously related to the widespread tendency of early Christian communities to identify themselves with the Verus Israel' ${ }^{4}$ In Ethiopia, Israelite descent was also claimed by the Zagwe themselves. Therefore 'the tradition of Israelite descent was not necessarily connected to the founding legend of the [Solomonic dynasty]. 5 The assumption that the Kəbrä Nägäst was compiled to legitimate Yəkunno Amlak's claim to the throne has similarly been put into question. The clergy responsible for the composition of the work hailed from the northern region of Təgray, where Aksum is located, and the Kabrä Nägäst could be read as their attempt to reassert the centrality of Aksum and Təgray at a time when the kingdom's centre of power was gradually shifting to the Amharic-speaking south. ${ }^{6}$ For Marrassini, the Kabrä Nägäst 'may well have been composed for [...] one or some of the ruling classes of Togray, against the claims of the south. [...] This agrees with the clearly "northern" traditions the [Kabrä Nägäst] elaborates; only subsequently it would have been adopted by the Solomonic dynasty'? 
Manuscripts of the Kəbrä Nägäst generally include dynastic charts, and while Solomonic descent was needed for a monarch to claim full legitimacy, mechanisms of succession were not overly stringent. There was no rule of primogeniture, for example, and this meant that often the transition of power was contested, resulting in a number of conflicts for succession. ${ }^{8}$ A succession crisis happened as early as 1294, after the death of Yəkunno Amlak's son and successor, Yəgba Șäyon. Yəgba Șäyon's five sons decided to rule one year each, but when it was fifth son's turn, he imprisoned his four brothers in order to rule without competitors. The institution of a royal prison seems to date back to this time and remained in place in the following centuries. Before moving to the Wahni mountain near Gondär in the seventeenth century, the prison was located on top of the Amba Gäšen, also known as the semimythical Amba Nägäst, the 'mountain of the kings'. The prison serving two main purposes: the sons, brothers, uncles and nephews of the ruling king were detained there to prevent coups and conspiracies, but at the same time the prison was also a way to protect them and guarantee the presence of an heir after the death of the ruling king. As such, the royal prison also served as a 'dynastical sanctuary." Through coercive institutions like the royal prison, in the medieval period the principle of patrilinear descent seems to have been followed without major exceptions. ${ }^{10}$ At the death of a king, it was one of his sons or, much more rarely, his brother to take power. Legitimacy could nevertheless be claimed from any branch of the broader lineage, and sons and brothers of earlier kings were also contenders for power. In the upper echelons of Ethiopian societies, multiple marriages were frequent, and so were divorces. ${ }^{11}$ In any case, Solomonic descent was only one of the qualities the monarch had to possess, military prowess and religious credentials being of equal, or perhaps even superior importance. Getatchew Haile states that king was 'one that has the kwinat, or in today's language, the gun. The question of royal blood does not seem, in fact, to concern the population' ${ }^{12}$ On top of this, the Kabrä Nägäst seems to have had limited circulation over the centuries. Far from what we would expect of a 'national epic', it was only used infrequently. ${ }^{13}$

The very same name 'Kəbrä Nägäst' was used loosely in history, not only to designate a single text, but a larger corpus of textual materials related to royalty. In Aksum the term referred to a fourteenth or fifteenth century collection of texts known to philologists as Liber Axumae. The story of Solomon and Sheba is for the most part absent from the Liber Axumae corpus. The manuscript narrating the holy genealogy of the city does not mention the arrival of the Ark, and celebrates the Queen of Sheba only as one of the city's several mythical leaders. ${ }^{14}$ More than celebrating the monarchy, whose capital had moved far to the south, the Liber Axumae glorifies Aksum itself as a second Jerusalem. The documents of the Liber Axumae narrate Aksum's history through a Christian, rather than Solomonic, framework, referencing the New Testament more than the Old. ${ }^{15}$ In Aksum, in other words, the term 'Kobrä Nägäst' designated a geographically-bound tradition of local prestige, not a 'national epic' legitimising the Ethiopian imperial dynasty. 
Hirsch and Fauvelle-Aymar have suggested that the documents of the Liber Axumae might have been initially compiled for Emperor Zär'a Ya'qob's coronation ceremony, held in Aksum in 1436. The pool of Biblical symbols of the Kəbrä Nägäst was nevertheless mobilised to show the ruler's Christian credentials and not so much his Solomonic pedigree. Rather, it is another line of descent that emphasised, namely the Davidian one, which allows Zär'a Ya'qob to present himself as a Messiah, a Christ-like figure. ${ }^{16}$ Zär'a Ya'qob chose Aksum as a site for his coronation in order to establish a continuity between his rule and the Aksumite kings of the past, but it is the 'essentially Christian character of Aksum more than its connection, via the Ark of the Covenant, to the Old Testament' that he was interested in highlighting. ${ }^{17}$ When we look at pre-twentieth century sources, therefore, we are forced to 'disconnect the history of the Solomonic dynasty from the history of the Solomonic myth'. ${ }^{18}$ The myth is said to have accompanied, or even regulated, the succession of Ethiopian rulers, but the Liber Axumae shows us that the Solomonic legend was not always a central part of the kingdom's political culture.

Lineage remained a requirement of monarchical legitimacy even in later periods of political fragmentation. During the Zämänä Mäsafant, the 'Era of the Princes' stretching from the mideighteenth century to the mid-nineteenth century, the power of the kings shrunk dramatically, as regional lords battled each other for supremacy. Monarchs kept being appointed from the Solomonic line, but most of them were no more than puppet kings. Since the seventeenth century, the medieval line of Solomonic kings had branched into several regional offshoots, whose families claimed descent from earlier royal ancestors within the broader Solomonic line. With the central monarchy in crisis, each of these regional ruling families 'attempted to maximize their holdings within the bounds allowed by their own military and political prowess vis-à-vis their peers'. ${ }^{19}$ Marriages were a key strategy to forge alliances, and in this period regularly extended to non-Christian lineages. ${ }^{20}$ As a result, the ruling houses of all the provinces, whether Christian or Muslim, became 'all interrelated either by blood or marriage' and thus 'constituted one inter-related and inter-twined elite ${ }^{21}$. Through marriage, several families that had been peripheral to the political game of the central monarchy acquired 'genealogical capital' and became power contenders. ${ }^{22}$ The majority of chiefs had in one way or another a viable Solomonic claim. Basing monarchical legitimacy exclusively on the Solomonic claim was almost meaningless in this context. The puppet kings of the Zämänä Mäsafənt may have had solid Solomonic claims, but still they held little or no power beyond their title.

It is in the second half of the nineteenth century that the Kəbrä Nägäst and its Solomonic myth become more closely connected with the history of the Ethiopian monarchy. Coming to power after a century of civil wars and institutional decentralisation, Emperors Tewodros II, Yohannəs IV and Mənilək II soon proceeded to reinforce 'the religious foundation of monarchical ideology'. ${ }^{23}$ The three rulers could not claim direct Solomonic ancestry through their fathers or grandfathers. Tewodros and 
Yonannəs had a claim only through the female line, and Mənilək's Šäwän relatives had started claiming Solomonic ancestry just a few generations before. The three emperors' efforts to reinforce monarchical symbols have been interpreted as a way to compensate for these dynastical limitations. Lacking a robust patrilinear link with the Solomonic line, they had to claim legitimacy through a broader ideological apparatus. ${ }^{24}$ In practice, though, no reigning king in this period 'attacked the dynastic legitimacy of his predecessors or rivals. [...] The weightiest charge which Ethiopian political rivals levied against each other was that of irreligion'. ${ }^{25}$ The systematic deployment of religious symbols on the part of the three kings was not necessarily the consequence of their lack of internal legitimacy. Monarchical legitimacy rather derived from the emperors' religious virtue, of which their genealogical pedigree was only one of several qualities. The dynastic issue was, from this point of view, 'just another way of proclaiming oneself to be a true and good Christian king, ${ }^{26}$

Hence, in this period of monarchical restoration the Kabrä Nägäst's prescriptions were being renegotiated, if not outright disregarded, but what was gaining importance about the text was the broader Solomonic myth it narrated. The literal interpretation of dynastical procedures was not as relevant as their ideological implications: 'the details were not at issue, it was their meaning'. ${ }^{27}$ And the meaning of legitimacy did not anymore only depend on domestic definitions. As Ethiopia's foreign relations intensified, external sources of legitimacy were becoming increasingly fundamental. There are hints that foreigners understood the Ethiopian monarchy through much more rigid conceptions of dynasty than the ones employed by Ethiopians themselves. The myth of the Kabrä Nägäst was known in Europe, and Europeans were fascinated by it. When they travelled to Ethiopia, they invariably asked questions. Thus, it is perhaps not a coincidence that 'our earliest reference to Tewodros's claim to Solomonic descent comes from the missionary Stern', who reported that the king's father was 'a reputed scion of Queen Sheba's royal line'. ${ }^{28}$ For Crummey, 'the casual character of [Stern's] reference is disarming. The earliest Amharic sources, contemporary with the reign, completely ignore the question, suggesting it was a minor matter'. ${ }^{29}$ Fittingly, when in 1863 Tewodros promulgates an edict about his Solomonic origins, he issues it 'to the European community at Gafat'. ${ }^{30}$

At the end of the nineteenth century, Ethiopia's relationship with the world was changing. In the fifteenth century, Zär'a Ya'qob could claim for Ethiopia a centrality that in the nineteenth century was difficult to justify. In Mənilək's diplomatic exchanges with his foreign counterparts, it was unfeasible to keep presenting Ethiopia as the new Jerusalem, the Holy Land of Christianity. Zär'a Ya'qob's project of Christian restoration was for internal use, aimed at redefining the monarchy in the eyes of its elites, clerics and subjects. Mənilək operated instead in an increasingly globalised world that looked to Palestine to find the holy Jerusalem of Christianity, not to Ethiopia. The Kəbrä Nägäst became a way for the Ethiopian elites to forge historical links with that faraway Jerusalem. 'Israel' becomes 'an external referent - whereas for Zär'a Ya'qob Ethiopia is Israel'. ${ }^{31}$ The Kabrä Nägäst takes up its role 
as 'national epic', in other words, when Ethiopia centrality is displaced, and Ethiopian rulers find themselves operating in an international scenario in which they occupy a marginal position. To support this point, Hirsch and Fauvelle-Aymar cite one of Mənilək's letters to Queen Victoria in 1872. In the letter, Mənilək states that Great Britain is the new Israel, due to its wealth, its territorial conquests, and the respect it had earned from other nations. ${ }^{32}$ The term 'Israel' is used by Mənilək in its political, more than theological, connotations: 'God', he tells Victoria, 'has made the English superior in science, friendship and government ${ }^{33}$ Mənilək writes to the ruler of the new Israel to ask that Ethiopia's links with the old Israel be recognised and, through these links, Ethiopia be accepted in international society. ${ }^{34}$ When this letter was written, Mənilək was king of the central region of Šäwa, but not yet emperor. His ideological activism became even more systematic after his 1889 ascent to the imperial throne.

Hence, Mənilək's chronicle starts off with a long retelling of the Solomonic tale, and makes an explicit connection between the ruling emperor and his namesake Mənilək I, the mythical son of Solomon and Sheba. The prominent recounting of the Solomonic dynastic myth at the beginning the chronicle is 'a very new fact'. ${ }^{35}$ The same could be argued for a whole array of monarchical paraphernalia that in the twentieth century were classified as 'ancient', such as the Lion of Judah. It was actually Mənilək who associated the symbol of the Lion to the monarchy. ${ }^{36}$ Overall, then, in the late nineteenth century, Ethiopian elites recuperated and redeployed some of the symbolic and narrative resources of the country's imperial past. Old traditions were re-accented, reinterpreted and bent to serve new objectives. Genealogical sources of monarchical legitimacy were already part of medieval political culture, but in the late nineteenth and even more prominently in the twentieth century they gradually underwent a strategic re-conceptualisation. Mənilək had already contributed to the process, but the transition from lineage as transcendental source of Christian political morality to dynasty as immanent source of sovereign political power was finalised by Ras Täfäri, later crowned Emperor Haylä Səllase (r. 1930-1974). Already as regent under Empress Zawditu (r. 1916-1930), Täfäri had increasingly started referring to the Kabrä Nägäst for legitimation purposes, but his ideological rebranding of the monarchy in dynastic terms, as we shall see in the next sections, reached its peak in the 1930s.

\section{The 1930 coronation: dynasty in ritual}

When Ras Täfäri was crowned Emperor Haylä Səllase in 1930, he launched a full-scale project to modernise the Ethiopian monarchy, from its symbolism and rituals to its relationship with the law. Ethiopia was surrounded by Italian, British and French colonies, and European expansionism was a looming threat. The Ethiopian monarchy's source of legitimacy was not anymore mostly internal, but came from foreign governments and international institutions as well. Internal conflicts could be used by Europeans as an excuse for invasion, and Haylä Səllase was aware that projecting an image of 
domestic stability and orderly government was key to maintaining his sovereignty. The redefinition, rigidification and systematisation of dynasty was a central component of his monarchical overhaul.

The 1930 coronation ceremony was held in Addis Abäba and designed, for the most part, as an international relations operation. The upper echelons of Ethiopian society were all in attendance, but the guests of honour were the official envoys of thirteen foreign governments. ${ }^{37}$ The ceremony was carefully planned in all its material and symbolic aspects over the course of seven months. In his autobiography, Haylä Səllase recounts studying the Sər'atä mängəst ['the order of the kingdom'], a collection of texts describing the procedures and customs of the Ethiopian monarchy, including the crowning of the king. ${ }^{38}$ The desire to pay homage to the tradition went hand in hand with a clear awareness that modifications were required. Haylä Səllase himself could not be more explicit about the reasons for innovating the ritual. In the past, he explains in his autobiography, the transition of power after a king's death was carried out in secret, and only publicly announced after the new king had already been crowned in a private ritual. But with the eyes of the world on Ethiopia, a coronation ceremony behind closed doors would send the wrong message:

As regards the succession to throne and crown, we have read in history that, at a time when Ethiopia lived in isolation and before she had established relations with foreign countries, the prevailing custom had been, at the demise of the Emperor, for his death often to remain carefully unannounced. They would then place his son and heir on the throne and crown him immediately that very day. Only after the son's reign and coronation had been announced by proclamation, would they give a ceremonial burial to the dead King.

[...] But now that Ethiopia had concluded treaties of commerce and friendship with twelve foreign governments, had entered the League of Nations, and had established firm friendly relations, We were convinced that it was proper - in accordance with the practice of the most civilized governments in the case of their coronations - to invite to Our coronation the countries which had set up legations and consulates in Ethiopia. ${ }^{39}$

Ethiopia's incorporation into the global system of interstate relations required domestic political power to be redefined. Of all the propaganda goals of the ceremony, reassuring the Europeans of the long-term sustainability of the Ethiopian modernisation plan was paramount. The Europeans had to be persuaded that if the Emperor died or became incapacitated, a peaceful transition of power would occur and foreign businesses and concessions would not be damaged. Hence, one of Haylä Səllase's first preoccupations was to establish clear mechanisms of dynastic succession. The coronation was the perfect setting to convey the message that the government would remain stable and continue in its reform path even after the end of his rule. In the ceremony, therefore, it was not only Haylä Səllase but also his family that received official recognition. Just after the Emperor was crowned, his son Asfa Wässän was appointed official heir. 'For the first time in Ethiopian history, a crown prince was installed', Marcus remarks, a move that broadcasted 'Haile Sellasie's [...] clear intention to start a dynasty'. ${ }^{40}$ The Emperor's autobiography gives us the details of the oath sworn by the prince: 
At this moment Our heir to the throne, H.H. Asfa Wassan, removed the coronet from his head and, when he knelt before Us, the Archbishop ${ }^{41}$ approached with a Gospel and asked him to take the following oath: (1) that he would honour his father with his whole heart and be obedient to him; (2) that he would not seek, in association with evil men, what We had not given him of Our own will; (3) that he would keep the laws which We had established after referring them, of Our own free will, to the Council for advice. After he had sworn to fulfil this, he appended his signature to it. ${ }^{42}$

Soon after, Haylä Səllase's wife and Asfa Wässän's mother, Mänän, was crowned queen, another conscious departure from the monarchical protocol:

Subsequently the coronation service of the Empress commenced. The procedure for the enthronement of the Empress is today very different from what it used to be previously. According to Our historical study of the earlier practice, the Empress was not anointed with the oil of kingship on the grounds that she did not share in rulership with the Emperor. The crown, being merely symbolic, was very small. It was in the palace that the Emperor placed the crown on her head and not in church. This occurred on the third day, for it was not permitted for her to be crowned on the same day as the Emperor. But now it was determined after consultation, and was accordingly carried out, that, except for the regal anointing, the Archbishop should place the crown on her and put the diamond ring on her finger and that this should be on the same day jointly with the coronation of the Emperor. ${ }^{43}$

Sohier suggests that the queen's new prominence during the coronation ceremony parallels similar changes abroad. In Great Britain, she notices, the presence of the monarch's spouse during the coronation ceremony only gained importance in the first decades of the twentieth century. ${ }^{44}$ In having Mänän crowned publicly just after him as part of the same ritual, Haylä Səllase wanted to make the ceremony more 'proper' (in his own words), that is, recognisable for his international guests. While possibly inspired by foreign developments, the publicly-sanctioned role given to the Emperor's family also signals 'Haile Selassie's willingness to impose himself with his immediate descendants at the head of the country ${ }^{45}$ Through elevating Mänän, Haylä Səllase was also emphasising the legitimacy of his designated heir.

\section{The 1930 coronation: dynasty in urban spaces}

Haylä Səllase's dynastic reinterpretation of monarchical ideology did not stop here. While officialising his family's imperial standing guaranteed continuity for the future, a parallel public relations operation was aimed at displaying continuity with the past. Particularly thorny for Haylä Səllase was the fact that he had risen to power in 1916 in a palace coup against Emperor Mənilək's legitimate heir, Lajj Iyasu ${ }^{46}$. The historiography produced under Haylä Səllase, subordinated as it was to the Emperor's own political agenda, tended to portray Iyasu's reign as negatively as possible or to dismiss its importance altogether. ${ }^{47}$ The same erasure characterised the urban makeover that Addis Abäba underwent for the coronation. The ceremony, as we have seen, was designed as a display of sovereign power. Addis Abäba underwent intensive renovations, with a frenzy of construction works 
and urban beautification projects taking place in the months leading up to the coronation. The Emperor personally supervised the works, as well as overseeing the creation of new uniforms for the military, new garments for the notables, and items symbolising imperial power such as crowns, rings, orbs and swords. Every detail was aimed at showing the world Haylä Səllase's ability to mobilise and administer economic and human resources. Symbols of dynastic continuity were inscribed in the urban fabric of the city, for all international guests to consume.

Just outside the train station where all the guests arrived, the Emperor placed the first public statue of the city's history, an imposing monument of the Lion of Judah. The engraved portraits, each on one side of the pedestal, of Empress Zäwditu, Emperor Mənilək, Haylä Səllase himself, and his father Ras Mäkonnən offered the onlookers a brief dynastic history of Ethiopia's recent past. Iyasu, who was in power for a not insignificant period of six years (1910-1916), is notably absent. The Lion of Judah statue presents therefore a 'fictive political continuity'. ${ }^{48}$ Other public monuments were built with the same goal in mind. Inaugurated for the occasion of the coronation was another statue, an equestrian monument of Mənilək II, located just opposite the church dedicated to St. George that had been built by Mənilək himself, and where Haylä Səllase's coronation took place. Unveiled at the presence of all foreign envoys the day before the coronation ceremony, the statue symbolised to the world the transfer of power from Mənilək directly to Haylä Səllase, effectively erasing the two decades of Iyasu's and Zäwditu's rule from Mənilək's death in 1910 to 1930.

The use of urban spaces for disseminating the monarchy's brand of nationalism responds to a political situation in which public opinion, both domestic and international, had become a central source of political legitimacy. The degree to which Haylä Səllase took charge of dynastic symbolism and disseminated meticulously-crafted historical narratives was impressive throughout his reign. Per se, however, the reworking of the Emperor's lineage to emphasise noble forefathers and hide potentially controversial ancestors was nothing new in Ethiopian history. Haylä Səllase's predecessors had already made ample use of real or mythical ancestors for legitimation purposes. What was new under Haylä Səllase is the insistence, through monuments, visual arts and historiography, that such historical continuity had been 'unbroken' and 'uninterrupted'. A modernised conception of dynasty was the main tool used to advance this claim.

\section{The 1930 coronation: dynasty in historiography}

Some of our main sources for the medieval and early modern history of the Ethiopian empire are the royal chronicles. The chronicles covered, for the most part, only the reign of a single ruler, and as such they were discrete and independent pieces of historical scholarship, although they remained in conversation with their textual antecedents. They often included lists of past notables, whether rulers, 
church fathers, or church patriarchs. Lists of monarchs were sometimes aimed at illustrating the genealogical validity of the ruling king's claim to the throne, as in the case of the biography of Iyasu II. ${ }^{49}$ Many of these lists are incomplete, and there are discrepancies between different manuscript sources. The order and number of the kings are rarely the same, and there are several spelling variations and inconsistencies in the dates. Some of these lists were dated, some were not. Some stretched all the way back to Adam, some started from David. These scattered fragments started being stitched together in the twentieth century. According to Toggia, it is only in the late 1920s that 'the chronological metanarrative of Ethiopian history refracting successive reigns of kings actually began'. ${ }^{50}$ The chronicles shared the implicit assumption that there was a genealogical continuity between present and past rulers, but now that assumption was made explicit, amplified, and erected as cornerstone of Haylä Səllase's nationalist ideology.

Həruy Wäldä-Selasse, one of the leading historians of the time and staunch supporter of Haylä Səllase, compiled a semi-finalised list of kings in his Wazema ('Eve'), a short volume conceived as a prelude to a more comprehensive work on Ethiopian history to follow. ${ }^{51}$ Wazema was published, rather hastily if we judge by the several chronological errors, to celebrate Täfäri's coronation as nagus ('king') in 1928, which preceded by two years his ascent to the imperial throne. ${ }^{52}$ The systematisation of the dynastic record was therefore closely tied to a specific political project. This is all the more evident if we compare Wazema with another document, a bilingual Amharic-French booklet distributed to the Ethiopian and foreign guests attending Haylä Səllase's 1930 coronation. The booklet is titled Yägarmawi Nagus Nägäst Kädamawi Haylä Səllase Yähyəwät Tarik Baçç̣əru Yätäṣafä, 'His Majesty King of Kings Haylä Səllase the First, Biography Briefly Written'. It does not seem to be far-fetched to attribute this 'Biography Briefly Written' to Horuy, considering that his Wazema had been part of a similar legitimising project two years before. The author of the 1930 booklet, at any rate, is intimately familiar with Horuy's previously-published works, cites from them, and references them to the readers. The booklet opens by detailing the Solomonic ancestry of Täfäri's father, Ras Mäkonnən, focusing on the branch of the lineage generally claimed by the rulers of Šäwä, from Ləbnä Dəngəl (r. 1508-1540) onwards. For a detailed chronology of the kings from Menelik I to Ləbnä Dəngəl, the author explains, the readers should consult Wazema. Wazema indeed greatly stresses the importance of lists of kings and bishops, 'comparing, in a rather ill-chosen metaphor, those who do not know the names and deeds of their kings to children whose conception of food does not go beyond breast-feeding, ${ }^{53}$ In another passage, the readers are again sent to another of Horuy's publications for more information about Täfäri's 1924 tour of Europe. Even if the author of the 'Biography Briefly Written' was someone else, it is hard not to see Horuy somewhat involved in the booklet's publication.

If Wazema is mostly concerned with Täfäri's domestic legitimation at the time when his internal rivals still constituted a threat, the 'Biography Briefly Written' had to legitimise his rule internationally. 
From here comes the need for a French version of the text, something that Wazema did not have. Ethiopian and foreign readers of the booklet are presented with a fictive dynastical continuity. The 'Biography Briefly Written' distorts the historical record with the aim of presenting Tafari's 1916 rise to power as perfectly lawful. Firstly, just like the new monuments inaugurated in Addis Abäba erased Iyasu's rule from public memory, the booklet manipulates Haylä Səllase's genealogy in the same direction. Haylä Səllase's Solomonic ancestry is traced backward from his father Ras Mäkonnən, a narrative that allows the author to omit the much more central branch of Šäwä's lineage that bred Menelik II and his grandson Iyasu, thus hiding the fact that Iyasu had a much stronger genealogical claim to the throne than Täfäri. As a result of the omission, the booklet can present 'the elevation of Tafari to the position of King of Kings as the direct continuation of the destiny of the rulers of Šawā, ${ }^{54}$ Secondly, the text insists on presenting Harär as a fiefdom of Ras Mäkonnən's family, which was not true, and Täfäri as his father's only heir, which was also not true, since after Mäkonnən's death Täfäri's older brother Yəlma and later Däjjazmač Balča Safo ruled Harär before Täfäri eventually took over the governorship. The booklet's author, in other words, 'counterfactually suggests that the powership over Hārar was already continuously in the hands of Tafari's dynasty, while in fact no dynasty of Hārar had even yet been formed'. ${ }^{55}$ Harär had only been conquered by the Empire in 1887, but presenting Täfäri's family as a local dynasty allows the 'Biography Briefly Written' to present Iyasu's removal of Täfäri from Harär as an illegal action. Iyasu abused his imperial powers and toppled a regional dynasty, therefore the coup against him was a restoration of lawful dynastic arrangements.

The same ideological manipulation is at work at the very beginning of the booklet, where the author uses the key adjective 'unbroken' (sayakwart) to describe Haylä Səllase's genealogical connection with Solomon. Lineage, as we have seen, had always been used for internal legitimation, and the monarchs of the past had frequently flaunted their genealogical connections with famous ancestors, but the accent on 'unbroken' is new. At a first glance, it is not completely clear what the term actually implies. Ancel and Smidt reason that 'unbroken' must mean that 'the line was documented without interruption, transferring the knowledge of royal descent over all generations, with all names documented', but this is not factually accurate. ${ }^{56}$ Haylä Səllase came from a minor female side-branch of the Šäwän dynasty, and the Šäwäns themselves only started claiming Solomonic descent a few centuries before the twentieth, when they became power contenders on the highlands. The term 'unbroken' would later be used in even more confusing ways, not only in association with the royal lineage, but with reference to Ethiopian history as a whole, and even in the context of the history of humanity in general, for example in Ayele's formulation that 'the Ethiopians are time-endowed people with a claim to uninterrupted long human development'. ${ }^{57}$ The expression 'uninterrupted history' is for Richard Reid 'a tautological coupling if ever there was one'. ${ }^{58}$ Taken literally, 'unbroken' and 'uninterrupted' raise more questions than offer answers. 
We have to understand 'unbroken' not as a descriptive, but as an ideological term. The concept of an 'unbroken' dynasty is a way to assert sovereignty. It was activated as a concept when not only the political survival, but also the cultural dignity, of the Ethiopian monarchy was put into question by European hegemony, racism, and expansionism. Ethiopian elites perceived their country as underdeveloped and backward at the time, but a record of 'uninterrupted' power allowed the Ethiopian government to politically appropriate past glories and claim them as 'ours', thus compensating for the political weakness of the present with the political greatness of the past. Dynasty was a narrative tool to structure history linearly, connecting a mythical antiquity to the present, and the present to an equallymythical future. European powers were internationally recognised as powerful based on their socioeconomic and scientific progress. The Ethiopian elites did not have a claim to greatness in the present, but, once they appropriated the glories of the past as a political achievement of Haylä Səllase's 'direct' forefathers, they could use those to counteract European characterisations of Ethiopia as intrinsically inferior. Ethiopia's present underdevelopment was just an accidental product of a series of unfortunate historical circumstances, but just as the monarchy had been capable of delivering progress in the past, the same monarchy would be capable of delivering progress in the future. From this point of view, the dynastisation of monarchy was mobilised as an anticolonial ideological weapon.

Ethiopia is not the only example of modern dynastic refashioning. In India, too, dynasty was remoulded with similar objectives in mind. Through the language of dynasty, Indian authorities could bolster their sovereignty against British colonialism and demand international recognition. ${ }^{59}$ Twentieth century Ethiopian elites demonstrated an early interest in foreign examples of monarchical ideologies and looked abroad for inspiration. The attempt to use dynastic nationalism to enhance claims to sovereignty brought Ethiopia close to another empire, this time Japanese one.

\section{The 1931 embassy to Japan: dynasty in constitutional law}

Among the foreign governments represented at Haylä Səllase's coronation ceremony was Japan, and in the couple of years after 1930 the diplomatic relations between the two countries markedly intensified. Japan had long been on the mind of Ethiopian intellectuals. As early as 1900, GäbräOgziabher Gila-Maryam (1860s-1914) was encouraging his readers to acquire modern knowledge, explaining in one of his poems that 'he who accepts it, fears no one/He will become like Japan, strong in everything, ${ }^{60}$ The admiration for Japan would remain a central element of Ethiopian political thought in the following three decades and a half. All the most prominent Ethiopian intellectuals at some point praised Japan as a model for Ethiopia to follow, and Japan was regularly mentioned on the pages of the newspaper Bərhanənna Sälam ('Light and Peace', founded by Täfäri in 1923). Taking the 1868 Meiji restoration as the moment that initiated Japan's transformation into a global power, Ethiopian thinkers 
such as Fitawrari Deressa Amänte and Wärqənäh Đšäte quantified Ethiopia's development lag at sixty years. In a 1925 speech, for example, Wärqənäh remarks:

Realizing that to be successful in life they ought to imbibe European knowledge and imbibe it fast, [the Japanese] began to work diligently and were able to reach in sixty years the level of development that it has taken others centuries. Let us follow this amazing and praiseworthy example of far-sightedness and resoluteness of an entire people. ${ }^{61}$

In this quote, Wärqənäh is praising Japan for the way it appropriated European knowledge; for him, Japan is a proxy model for how to make Ethiopia more similar to Europe. But for other intellectuals, Japan represented the opposite: not an example of how to Westernise, but an alternative to the European model. The Japanese had managed to reinvent the political significance of the monarchy by presenting it as the main driving agent of modernisation. Ethiopia could do the same, and dynasty was central to this project.

The way in which Ethiopian intellectuals conceived the 'modern' dynastical monarchy was a combination of the Amharic concepts of sar (vein, artery, root) and sarat (procedure, system, regulation, order). The two concepts equally contributed to the ideological renewal of the monarchy that the Ethiopian ruling elites sought to achieve. Sor offered the monarchy historical depth and continuity, a connotation of antiquity and resilience. Srat gave that continuity a sense of linear progression, a specific teleological orientation, an eschatological meaning of moral triumph over the evil of chaos. The two concepts together give us sar wätt mängast, a 'dynasty which claims uninterrupted rule from ancient times to the present', that is to say a transhistorical continuity methodically stretching from the past to a pre-ordained political destiny in the future.

To the Ethiopian reader, the first article of the Meiji constitution must have exemplified this conception in the most striking way: 'The Empire of Japan shall be reigned over and governed by a line of Emperors unbroken for ages eternal'. An eternal, unbroken line of emperors: this was precisely the national and nationalist paradigm informing how Ethiopia's past was being rewritten. But beyond the content of this first article, the genre of the constitution itself was relevant for Ethiopian thinkers. Rituals, customs and symbols were powerful tools to attain sarat, but alongside them the law was an equally powerful tool. Of all these technologies of power, the law offered the added advantage of speaking the language of the international community. For the European powers at the League of Nations, after all, political order was not the implementation of divinely-ordained moral principles, but evidence of the rule of law. It was the immanent and secular rather than transcendental and religious elements of sarat that projected international legitimacy. That the Japanese had used the law to both modernise dynasty and dynastise modernity must have struck the Ethiopians as a masterful pushback against the Eurocentric claims that modernity meant a liberalisation of political space. The first article of the Meiji constitution used a European genre and European phrasings to assert the validity of the 
absolute monarchy. For the monarchy to claim international legitimacy, it just had to be made 'legal'. No transition to democracy was necessary. If for the Europeans sovereignty was predicated on upholding of the law, then obeying the constitution in protecting the monarchy could not but constitute an undeniable expression of Japanese sovereignty. All the more reasons to see Japan's 'eternalist clause' as a brilliant ideological checkmate against the diktats of the League of Nations and the international community.

The very promulgation of a constitution, after all, could be paraded as evidence of political modernity. On top of this, through the constitution the Ethiopian government could effectively legalise its own sovereignty. Constitutional law, from this point of view, offered the tools through which dynasty was redefined in twentieth century Ethiopia. And indeed, one of the first moves of the newly-crowned Emperor Haylä Səllase was to task his closest collaborators with the drafting of Ethiopia's first constitution. One of the main authors of the final document, Täklä-Hawaryat Täklä-Maryam, wrote candidly about the objectives of the whole operation in his autobiography. The point of the constitution issued in 1931, he reminisces, was 'to let foreign governments know that Ethiopia had a constitution and that its government was therefore constitutional, and to answer allegations of arbitrariness, feudalistic rule, undefined administrative procedures and chaotic government' ${ }^{62}$ That the constitution was essentially aimed at scoring credibility points on the international scene rather than at reforming the country domestically is demonstrated by its absolutist nature. De facto, the constitution mostly officialised what was already the case in the country - that the emperor had limitless, absolute powers and could govern according to his will. Sure enough, a bicameral Parliament was instituted, but it had a merely consultative role, and the Emperor could dissolve it if he wanted. All in all, the 1931 constitution acted 'more as vehicles of strong monarchical government than as platforms for genuine popular representation'. ${ }^{63}$ Rather than an attempt at democratisation, then, we can interpret the constitution as an anticolonial weapon and a device for diplomatic self-affirmation.

Dynasty was the perfect solution against foreign allegations of chaos and arbitrariness, at once tool of local centralisation and of global assertiveness. Indeed, institutionalising dynasty was one of the priorities of the constitution:

Art. 3. By law it is decided that the imperial prerogative will not depart from the descendants of Haylä Səllase I, born to King Sahlä Səllase's seed - a connected lineage that comes from Mənilək I, son of King Solomon of Jerusalem and the Queen of Ethiopia, known as the Queen of Sheba. ${ }^{64}$

Art. 4. The throne and the crown of the empire shall be transmitted to the children of the Emperor according to the written law of the imperial house. ${ }^{65}$

If article 3 is reminiscent of Japan's 'eternity clause', this was certainly not a coincidence. Many of the articles of the 1931 constitution are closely modelled on the articles of the Meiji constitution, and a clause-by-clause analysis of the two texts reveals striking similarities. ${ }^{66}$ Täklä-Hawaryat declares in his 
autobiography that he prepared the first draft by consulting the copies of the German, Italian, Japanese and English [sic] constitutions, ${ }^{67}$ but, if we judge by the final result, the Japanese influence clearly proved the greatest. It is dubious whether it was really Täklä-Hawaryat's decision to borrow so heavily from the Meiji model. Täklä-Hawaryat's draft was subsequently reviewed by Həruy Wäldä-Selasse, Ras Kassa and Haylä Səllase himself. ${ }^{68}$ The name of Həruy Wäldä-Selasse should alerts us that perhaps the Meiji influence was mediated by someone else.

Həruy, whom we have already encountered as author of Wazema and possibly of the 'Biography Briefly Written', was perhaps the most high-profile of those intellectuals that came to be known as Ethiopia's 'Japanisers'. As Minister of Foreign affairs, he led an Ethiopian diplomatic delegation to Japan in late 1931, organised to reciprocate the presence of Japanese envoys at Haylä Səllase's 1930 coronation. The main objective of the visit was to develop closer commercial ties and stimulate Japanese investments in Ethiopia. The Ethiopian delegation received a warm welcome by Emperor Hirohito himself, to whom Həruy announced Ethiopia's determination to follow in Japan's footsteps. In the forty days they spent in Japan, Həruy and his party attended a number of official receptions and visited factories, offices, industrial farms, zoos, theatres, railways, shrines, museums, and military training schools. Həruy came back to Addis Abäba convinced that an alliance with Japan should be a foreign policy priority for Ethiopia. Keenly aware of the importance of narrative in directing political choices, he soon moved to lay the ideological foundations for the alliance. His booklet Mahdärä Barhan Hägär Japan ('The Place of Light: The Country of Japan') was published in Ethiopia in 1932 and was promptly translated into Japanese by Oreste and Enko Vaccari. The Japanese translation was published in Tokyo in 1934, with a preface penned by the Japanese Minister of Foreign Affairs Kijūrō Shidehara. ${ }^{69}$ Həruy's argument insists on the similarities between Ethiopia and Japan, while strategically overlooking the elements of difference.

Of all the similarities, Həruy is particularly interested in stressing dynastic continuity as a remarkable feature of both countries. Both Ethiopia and Japan, he writes, have been ruled by long and 'unbroken' imperial lines. Hirohito is the $124^{\text {th }}$ monarch of the Jimmu dynasty, while Haylä Səllase is the $126^{\text {th }}$ of the Solomonic dynasty. Both empires had for centuries itinerant capitals. The Tokugawa Shogunate (1600-1868), as a period of decentralised political authority, is comparable to the Ethiopian Zämänä Mäsafant (1769-1855). In his reassertion of centralised imperial power, Meiji was similar to Mənilək II. It is surprising, Həruy concludes, that two countries with such similar histories had remained for such a long time oblivious of each other. As a work of historical scholarship, Mahdärä Barhan Hägär has several weaknesses. Həruy's comparison between Ethiopia and Japan 'suffered all too often from inadequate understanding of pre-Meiji Japanese history' ${ }^{70}$ According to Bahru Zewde, Həruy was essentially mistaken in asserting that Ethiopia and Japan were at the same stage of social development until the Meiji restoration. ${ }^{71}$ Həruy uses this particular argument to reinforce the quantification of 
Ethiopia's lag at sixty years, and build confidence in his readers that if Japan made it, then Ethiopia could make it too, and in a similar amount of time.

Mahdärä Barhan Hägär, from this point of view, is a transparent attempt at building a unilinear narrative of historical progress, in which political continuity is expressed through dynasty. The monarchy per se could offer Həruy enough ground to 'invent' historical continuity: the monarchy, after all, had been an institutional presence on the Ethiopian highlands for centuries. Dynasty, however, allows Həruy to build an even stronger case for continuity, since it confers order and coherence to the presence of the monarchy in time. There is a line linking all monarchs, and this line draws a pattern for the nation's past that can be projected forward into the future. Dynasty gives the monarchy a stable story and a unitary plot, through which Həruy can define Ethiopia's political identity and make predictions about its future glories. From this point of view, it is easy to see why Həruy is so impressed by Japan. He perceives the eternalist and theological connotations of the Japanese monarchy as something he could borrow in his attempt to give a clear directionality to Ethiopian history.

\section{London 1936: dynastic nationalism in action}

Narrating Ethiopian history as characterised by an uninterrupted dynastic stability entailed a shift of emphasis and indicates a change of audience. In a globalised world increasingly divided between colonisers and colonised, dynasty was meant for external consumption as much as domestic nationalism. The mythical rebranding of Ethiopia was extremely successful in capturing the imagination of at least a segment of European society. The elites of the Ethiopian empire had for centuries interacted with Europe through effective campaigns of cultural diplomacy. Fifteenth- and sixteenth-century Ethiopian travellers and envoys played along with European fantasies about distant Christians, such as the legend of Prester John, or the myth of the Black Magus. ${ }^{72}$ Ethiopian visitors to Europe "proved capable and willing to entertain the confused notions of their interlocutors and possibly exploit their expectations about the distant land from which they hailed'. ${ }^{73}$ As the Ethiopian visits to Europe intensified, 'Ethiopians seem to have adopted an increasingly proactive attitude, co-opting the discourse [of Prester John] to their own benefit'. ${ }^{74}$ The legend of Solomon and Sheba did not seem to have been particularly relevant to these early modern interactions, while the European tales of Prester John offered the Ethiopians much more space for political manoeuvre and ideological manipulation. In the twentieth century, it was rather the opposite. Tales of Prester John had long been debunked, and instead the Solomonic myth started offering more propaganda possibilities. Wendy Belcher has stressed the discursive power of the Ethiopians throughout history. Their self-representations 'have disseminated far beyond its shores and animated others' representations of them' ${ }^{75}$ The ideological broadcasting was successful in influencing what distant foreigners thought, enabling the Ethiopians to maintain and extend power over their neighbours and beyond. ${ }^{76}$ 
Such discursive agency did not wane in the twentieth century, even in the context of increased international hostility towards Ethiopia. Despite the Ethiopian efforts at cultural diplomacy, most Europeans continued to describe Ethiopia through racist and Eurocentric lenses. For novelist and journalist Evelyn Waugh, who attended Haylä Səllase's coronation and covered the Italo-Ethiopian conflict in 1935, the Ethiopians were 'by any possible standard an inferior race' ${ }^{77}$ The build up to the war in Fascist Italy was premised on dehumanising tales of Ethiopian savagery. And yet, the fascination that some Europeans developed for Ethiopia's Solomonic heritage did prove politically consequential. Some anti-Fascist movements in Europe reacted with dismay at the Italian invasion, and Ethiopia's carefully-crafted image of an old Biblical nation came in handy to amplify the outcry. The narratives of continuity enabled by the dynastisation of history were incredibly successful in invigorating the proEthiopian, anti-Fascist front, and we can trace this Ethiopian ideological success by looking at the newspaper New Times and Ethiopia News.

New Times and Ethiopia News was the weekly London-based newspaper founded and edited by Sylvia Pankhurst as a forum of pro-Ethiopia activism and anti-fascist mobilization. The first issue was published on the $5^{\text {th }}$ of May 1936, the day the Italians took Addis Abäba. Pankhurst was already known as a suffragette, leader of the movement for the Votes for Women, and anti-fascist campaigner. She reacted indignantly at the news of the Italian aggression against a fellow member of the League of Nations. When New Times and Ethiopia News was launched, Pankhurst had never been to Ethiopia and she knew little about the country, but whatever she did not have in terms of knowledge, she made up for with her energy and commitment. She had taken an interest in Ethiopia as an extension of her antiFascist campaigning, but when she embraced the Ethiopian cause, she did it with no reservations. Her enchantment with Ethiopia was total, her loyalty to Haylä Səllase firm and verging on adulation.

The Emperor and some of his close collaborators had arrived in the UK in June 1936, following the defeat of the Ethiopian army at the battle of Mayçäw. Pankhurst soon became one of the most unwavering political allies of the exiled Ethiopians. Different interpretations have been put forward regarding the relationship between Pankhurst and the Ethiopian delegation. Romero argues that Pankhurst was over-reliant on the information fed to her by the Ethiopians, who soon realised how useful she was and did not hesitate to take full advantage of her. Pankhurst published everything they told her, uncritically and without verification. She 'swallowed every word, every argument, and made no attempt to balance the account ${ }^{,}{ }^{78}$ The one-sidedness of Pankhurst's articles was aimed at contrasting the pro-Italian stance of British conservative newspapers, and as such, served a clear political purpose. But it is equally apparent that the Ethiopian delegation used New Times and Ethiopia News as a venue for a full-scale ideological offensive. The newspaper became a mouthpiece for Ethiopian nationalism, accentuating and amplifying the notions of antiquity, continuity and dynasty that had become 
centrepieces of the Ethiopian monarchical ideology. The Kəbrä Nägäst, surely enough, makes several appearances.

The articles written by Hazel M. Napier are a perfect example of this. Napier regularly contrasted Italian propaganda via fabulous descriptions of Ethiopia's biblical glory. To Mussolini's celebration of Italy's ancient independence, she retorts:

What of the ancient glory and civilisation of Ethiopia? There are obelisks in the Holy City of Axum cut in prehistoric signs, monoliths larger and possibly of greater antiquity than any in Egypt. [...] Here Makeda, the Queen of the South - or the Sun - ruled in all her glory. [...] There are wonderful eleven churches at Lalibali hewn out of rock in the reign of King Lalibala in the $12^{\text {th }}$ century. The design of the church was revealed to King Lalibala in a dream. Angels worked by day with the labourers and by night these celestial beings carried on the glorious work. [...] The Court ceremonies of Haile Selassie - the shining candelabra, the golden stool, the kettledrums of silver, the trumpeters - also the religious pageantry - the finely embroidered vestments, the gorgeous cloaks, the golden crosiers, the jewelled crowns, the systra, the drum - all reflect the glory of 3,000 years. ${ }^{79}$

Pankhurst was enchanted with the same myths. On the $19^{\text {th }}$ of September 1936, she published, under the title 'Abyssinia's Ancient Freedom', a review of Post Wheeler's lavishly-titled book The Golden Legend of Ethiopia, The Love story of Mâquedâ, Virgin Queen of Axum and Sheba, and of Solomon, the Great King. In Pankhurst's description, Ethiopian history is marked by a transhistorical stability and unity, and dynasty is what creates such unity and maintains such stability:

The names of the Queen of Sheba and King Solomon of Judah, which reverberate still in popular knowledge, because of their place in Biblical history, gain a new reality for us to-day from the sad martyrdom of Abyssinia. We remind ourselves: it was there the Queen of Sheba reigned. It was there she held her ancient pomp and power three thousand years ago. [...] The belief of the Ethiopians in the 'Kebra Nagast' has given remarkable stability and continuity to the kingdom. There have been rebellions and civil wars plenty, but the ideal unity of Ethiopia under its royal house descended from the royal house of Judah has always been in the background, to re-emerge under every strong king of the line of Solomon. ${ }^{80}$

Pankhurst's Ethiopia is 'a pre-Raphaelite world', an enchanted 'paradise lost', often portrayed through a generous dose of romantic primitivism. ${ }^{81}$ From the quote above it is evident that for Pankhurst dynasty is the basic 'plot' of Ethiopian history. The Ethiopian story, the Ethiopian identity are both premised on dynasty. She campaigned for Ethiopia out of internationalist political solidarity, but also out of a deep emotive fascination with Ethiopia's dynastic legend. The description of Haylä Səllase published on New Times and Ethiopia News does not portray the Emperor as a fallen political ally, but as a saint, a holy man, or, in Napier's words, a 'prophet':

Who is this small figure touched with frailty and yet so compelling, so indomitable? I do not know when I have felt such tragic stillness and quiet intensity. He seems remote from the guests who come to pay him homage, apart even from his own family and subjects who stand near him. His dark mystical eyes set in an oval of ivory are gazing at something afar. What do they see? [...] What does he see as he stands there in his royal black cloak with the face of a prophet? ${ }^{82}$ 
Articles like this are the product of an unmitigated narrative success on the part of the Ethiopian elites. It seems beyond doubt that the Ethiopian government in exile shaped the editorial line of New Times and Ethiopia News, although it is harder to assess to what extent. The delegation knew which notes to hit with Europeans and they were skilled in manoeuvring their European supporters. The effort that had gone in tweaking the message of Ethiopian nationalism in the first three decades of the twentieth century paid off. The neo-Solomonic nationalism did not manage to unseat the hegemonic European narratives of Ethiopian inferiority, but it managed to win over some of Europe's political fringes. Pankhurst and her collaborators were eager converts, and through New Times and Ethiopia News they further spread the image of an old, resilient nation ruled for centuries by monarchs whose lineage stretched back to biblical kings.

The power of Ethiopian monarchical narratives generated a bewildering political short circuit, as the republican, feminist and socialist Pankhurst became the main European apologist of an authoritarian and patriarchal king. 'New Times is opposed to the conception of dictatorship', declares the first issue of the newspaper, before proceeding to idolising Haylä Səllase, an absolute monarch that had risen to power in 1916 via a palace coup. According to Romero, 'Sylvia was overwhelmed by Haile Sellassie. Her republicanism departed from Waterloo station in June 1936, when the emperor's train rolled in ${ }^{83}$ Historians struggle to account for Pankhurst's ideological incongruity:

How did Sylvia Pankhurst, the socialist and republican, become a starry-eyed defender of an emperor? Part of the explanation lies in her strong anti-imperialist, anti-fascist and anti-racist sympathies. Pankhurst loved to defend the underdog and she saw in Selassie much more a defeated victim of fascism than a reactionary monarch. [...] Whatever the reason, the defence of Ethiopia and Selassie became her total focus. ${ }^{84}$

The appeal of dynastic mythologies had not disappeared in Europe, and a significant part of British intellectual and political elites celebrated the monarchy as consonant with political modernity. Dynasty is for Pankhurst a marker of civilization, and made Ethiopia's past easily legible and narratable. Ethiopia is civilised, Pankhurst tells her readers, because it is old and Biblical and imperial. Her activism did much to reinforce Haylä Səllase's power, not only during the Italian occupation, when the political imperatives of anti-fascist advocacy justified her firebrand approach, but also for the fifteen years after the liberation of Ethiopia from Italian rule: New Times and Ethiopia News ran until 1956 with the same editorial line. The politics of international solidarity that inspired the newspaper was concerned with the rights of the imperial elites, not so much for the oppression of peasants, labourers and ordinary people along class and ethnic lines.

In reflecting on New Times and Ethiopia News, we are confronted on the systematic ambiguity of 'dynasty' in Ethiopia. Abroad, it was used to articulate resistance against European and white domination, but those foreigners who embraced it as counter-hegemonic weapon ended up reinforcing 
an authoritarian, anti-democratic state whose exploitative economy and illiberal policies had long been criticised domestically by Ethiopian intellectuals themselves. ${ }^{85}$

\section{New York 1937: dynastic nationalism in action}

An intellectual history of dynasty in the Ethiopian context sees the concept simultaneously associated with both hegemonic and counter-hegemonic political projects. This ambiguity is particularly profound if we look at the role of Ethiopia within Pan-Africanism and black nationalism. In parallel to New Times and Ethiopia News, another newspaper was launched to defend Ethiopia at the time of the Italian invasion. Voice of Ethiopia was published in Harlem by Mälaku Bäyyan, an Ethiopian medical doctor who had embraced the black cause while studying abroad at Howard University. Mälaku had served at the front during the 1935-1936 war, but after the Mayç̣äw defeat Haylä Səllase sent him back to the US to enlist the support of black Americans and raise funds for the UK-exiled Ethiopian government. ${ }^{86}$ Voice of Ethiopia, launched in 1937, was mostly addressed to African-Americans and was prefaced by slogans directly inspired by black nationalism, such as 'Black men, Ethiopia is yours' ${ }^{87}$ Although less systematically than New Times and Ethiopia News, Voice of Ethiopia played with images of an ancient black dynasty, ruling for millennia a nation with an old history of African Christianity. The newspaper was the first systematic engagement of Ethiopian state authorities with Ethiopianism, the ideology of African liberation embraced by secular and religious movements in South Africa, North America and the Caribbean. Many of these movements celebrated Haylä Səllase's ascent to the imperial throne as the realisation of the prophecy in Psalms 68:31 that 'Ethiopia shall stretch her hands to God'. Dynasty gave these movements the possibility of accessing and laying claim onto a historical depth that was denied to them by slavery and racism. The Rastafari movement, which considered Haylä Səllase divine, studied the Kabrä Nägäst, and republished it several times as 'the lost Bible of Rastafarian wisdom and faith'. Ethiopia was thought to stand for the whole of the African continent and the black race as a beacon of freedom and independence. Voice of Ethiopia successfully amplified these preexisting narratives, and it seems that its Harlem readership was quite numerically significant.

The claims that the Ethiopian imperial elites made through New Times and Ethiopia News, though, went into another direction. In an article titled 'A Just Solution', Wärqenäh Đšate, whose praise of Japan we have cited above, calls for an international diplomatic summit in which

the Powers which in one way or another have acquired colonies in the past should bravely agree to hand over the independence of the colonies to their original owners, under the condition that the territories whose owners and inhabitants happen to be backward in knowledge shall remain, for the time being, under the supervision of the League of Nations and shall be helped to make the necessary progress. ${ }^{88}$

Italy was wrong in invading Ethiopia, in other words, because Ethiopia was already an advanced civilisation. But if civilisation was measured by shining candelabra and jewelled crowns, how does the 
argument apply to the rest of Sub-Saharan Africa, whose societies did not have myths of origin that were as appealing to white Europeans as Ethiopia's biblical legends? Dynasty is used in this argument to stress Ethiopia's difference from the rest of Sub-Saharan Africa. The territories 'backward in knowledge', Wärqenäh tells us, need the civilising hand of the League of Nations in order to make 'the necessary progress', but Ethiopia already had a legitimate ruler committed to modernising his country.

Arguments like these inevitably alienated some of Ethiopia's black supporters. Marcus Garvey, the all-influential leader of the Universal Negro Improvement Association (UNIA), and up until then a committed Ethiopianist, grew increasingly critical of Haylä Səllase. When Haylä Səllase fled Ethiopia after the Mayçäw defeat, Garvey decried that 'the last Emperor of Ethiopia has surrendered the ancient sceptre wielded for ages by a historic line of black sovereigns'. But was Haylä Səllase really committed to his black brothers and sisters? Rather the opposite, Garvey wrote in a scathing editorial on Black Man. Haylä Səllase 'wanted to play white', was 'a slave master', 'too silly to take pride in his race' and he '[thinks] himself better than the Negro who constitutes the larger number of Ethiopia'. ${ }^{89}$ Garvey makes a crucial point here. The ideology of dynasty deployed so effectively by the Ethiopian delegation in the UK associated civilisation with antiquity, Christianity and monarchical sovereignty. But this only describes a minority of the population of the Ethiopian state. Many of them spoke languages other than Amharic, were Muslims or followers of traditional religions; some groups were pastoralists and nomads, and had decentralised political structures before Mənilək's army conquered them at the end of the nineteenth century and forcibly subjected them to Addis Abäba's rule. Slave raids usually targeted non-Christian groups, who often had a darker skin complexion compared to the Christian highlanders. Dynasty, with the ancient monarchical sovereignty it evoked, was used to justify the superiority of Christian highlanders vis-à-vis the 'less developed' cultures of the lowlands. ${ }^{90}$ The argument underlying Garvey's vitriolic accusation is that Haylä Səllase was an 'Amharic white loving Emperor who liked to chain and flog black men'. ${ }^{91}$ Haylä Səllase could not let this pass, especially in a moment of political vulnerability in which he needed all the support he could muster, and he enlists Mälaku Bäyyan for the ideological counter-offensive. Voice of Ethiopia was launched precisely with the objective of countering Garvey's argument, and the first four issues are dedicated to a powerful rejoinder against Garvey's position.

Mälaku unreservedly identified with the black and Pan-African cause, but remained an isolated, and somewhat exceptional, figure in the Ethiopian intellectual landscape of the time. ${ }^{92}$ If Voice of Ethiopia was successful in galvanising black support for Ethiopia in Harlem, it certainly did not manage to solve what Asafa Jalata called 'the duality of Ethiopianism'.${ }^{93}$ At the end of the 1960s, the Ethiopian student movement attacked the claim to antiquity that the Ethiopian imperial elites had made through the narrative of dynasty. Enough with the Solomonic tales of three millennia of 'unbroken' dynastical history, they argued. Ethiopia was but a modern invention, built through blood and conquest by Emperor Mənilək at the end of the nineteenth century. Marginalised ethnic groups accused Solomonic elites of 
hypocrisy for the way they pandered to Pan-Africanism while de facto perpetuating a domestic system of cultural domination. Hailing from one of these historically marginalised Ethiopian groups, Asafa denounced that

Successive Ethiopian state elites have used the discourses of civilization, race, culture, and religion to justify and rationalize the colonization and dehumanization of the indigenous Africans, such as Agaos, Oromos, Ogaden-Somalis, Afars, Sidamas, and Walayitas, and have selectively utilized the politics of Africanness or Blackness without actually practicing this aspect of Ethiopianism. ${ }^{94}$

The ambiguity of dynasty remained open, its legacy harshly contested. Was it a tool of ethnic domination? Was it an instrument for diasporic blacks to imagine a future of freedom? Was it a primitivist dream of white Europeans disillusioned with modernity? Was it an internationalist tool for the left to mobilise against fascism? Was it a way to build South-South political alliances able to eschew the Eurocentric traps of international law and international relations? Dynasty was well and alive in the twentieth century. It was theorised and counter-theorised around the globe, from Tokyo to Harlem, spearheading some political projects, being the prime polemical target of others, fighting some inequalities while reproducing inequalities elsewhere. In the case of Ethiopia, dynastic nationalism was a central feature of political modernity, and was transnationally co-constituted by a variety of agents moving across the world. From the vantage point of Ethiopia, an intellectual history of dynasty cannot but be a global intellectual history.

\section{References}

Note: there are no family names in Ethiopia and Ethiopian authors are cited by their first name followed by their father's name.

Ancel, Stéphane, and Wolbert Smidt. "Legitimization of a Pretender to the Throne: A Short AmharicFrench Biography of Hāyla Sellāsē I Published in 1930." Annales d'Ethiopie 28 (2013): 203238. https://doi.org/10.3406/ethio.2013.1535

Asafa Jalata. "Being In and Out of Africa: The Impact of Duality of Ethiopianism." Journal of Black Studies 40, no. 2 (2009): 189-214.

Ayele Bekerie. "The Ethiopian Millennium and its Historical and Cultural Meanings." International Journal of Ethiopian Studies 3, no. 2 (2008): 23-31.

Bahru Zewde. Pioneers of Change in Ethiopia: The Reformist Intellectuals of the Early Twentieth Century. Oxford: James Currey, 2002.

Bahru Zewde. Society, State and History: Selected Essays. Addis Ababa: Addis Ababa University Press, 2008.

Banerjee, Milinda. The Mortal God: Imagining the Sovereign in Colonial India. Cambridge: Cambridge University Press, 2017.

Belcher, Wendy. Abyssinia's Samuel Johnson: Ethiopian Thought in the Making of an English Author. Oxford: Oxford University Press, 2012.

Budge, E. A. Wallis, ed. and trans. The Queen of Sheba and Her Only Son Menyelek. London: Humprey Milford, 1922.

Carnochan, W. B. Golden Legends: Images of Abyssinia, Samuel Johnson to Bob Marley. Stanford: Stanford University Press, 2008. 
Clarke, J. Calvitt III. Alliance of the Colored People: Ethiopia and Japan Before World War II. Rochester (NY): James Currey, 2011.

Constitution d'Ethiopie/YäItyopya Həgä Mängəst. Addis Ababa,1931.

Crummey, Donald. "Society and Ethnicity in the Politics of Christian Ethiopia during the Zamana Masafent." The International Journal of African Historical Studies 8, no. 2 (1975): 266-278.

Crummey, Donald. "Imperial Legitimacy and the Creation of Neo-Solomonic Ideology in 19th-Century Ethiopia." Cahiers d'Études Africaines 28, no. 109 (1988): 13-43. https://doi.org/10.3406/cea.1988.2150

Derat, Marie-Laure. Le Domaine des Rois Éthiopiens (1270-1527): Espace, Pouvoir et Monachisme. Paris: Sorbonne, 2003.

De Lorenzi, James. Guardians of the Tradition: Historians and Historical Writing in Ethiopia and Eritrea. Rochester (NY): Rochester University Press, 2015.

Eadie, JI. An Amharic Reader. Cambridge: Cambridge University Press, 1924

Fikru Negash Gebrekidan. Bond Without Blood: A History of Ethiopian and New World Black Relations, 1896-1991. Trenton (NJ): Africa World Press, 2005.

Fiquet, Éloi. "Understanding Lïj Iyasu Through His Forefathers: The Mammedoch Imam-s of Wello." In The Life and Times of Lï Iyasu of Ethiipia: New Insights, edited by Éloi Fiquet and Wolbert G. C. Smidt, 5-29. Berlin: Lit Verlag, 2014.

Garvey, Marcus. "The Failure of Haile Selassie as Emperor." The Black Man 2, no. 6 (1937): 8-9.

Getatchew Haile. "Review of Bairu Tafla (ed), A Chronicle of Emperor Yohannes IV (1872-89), Athiopistische Forschungen, vol. 1." Northeast African Studies 3, no. 2 (1981): 73-84.

Haile Selassie I. My Life and Ethiopia's Progress, vol 1: 1892-1937 (translated and annotated by Edward Ullendorff). Oxford: Oxford University Press, 1976.

Heran Sereke-Brhan. “'Like Adding Water to Milk': Marriage and Politics in Nineteenth-Century Ethiopia.” The International Journal of African Historical Studies 38, no. 1 (2005): 49-77.

Hirsch, Bertrand and François-Xavier Fauvelle-Aymar. "Aksum après Aksum: Royauté, Archéologie et Herméneutique Chrétienne de Ménélik II (r. 1865-1913) à Zär’a Ya qob (r. 1434-1468).” Annales d'Ethiopie 17 (2001): 59-109. https://doi.org/10.3406/ethio.2001.991

Kaplan, Steven. "Solomonic dynasty." Encyclopaedia Aethiopica He-N, edited by Siegbert Uhlig, 688690. Wiesbaden: Harrassowitz Verlag, 2007.

Kropp, Manfred. "Notes on Preparing a Critical Edition of the Śrr 'atä Mängəśt." Northeast African Studies 11, no. 2 (2011): 111-140.

Levine, Donald. Greater Ethiopia: The Evolution of a Multiethnic Society. Chicago: University of Chicago Press, 1974.

Marcus, Harold. Haile Sellassie I: The Formative Years 1892-1936. Berkeley: University of California Press, 1987.

Marrassini, Paolo. "Kəbrä Nägäśt”. In Encyclopaedia Aethiopica He-N, edited by Siegbert Uhlig, 364368. Wiesbaden: Harrassowitz Verlag, 2007.

Meseret Chekol Reta. The Quest for Press Freedom: One Hundred Years of History of the Media in Ethiopia. Lanham (MD): University Press of America, 2013.

Molvaer, Reidulf Knut. Black Lions: The Creative Lives of Modern Ethiopia's Literary Giants and Pioneers. Lawrenceville (NJ): Red Sea Press, 1997.

Napier, Hazel M. "The Glory of Ethiopia." New Times and Ethiopia News (21 November 1936).

Napier, Hazel M. Untitled. New Times and Ethiopia News (17 June 1936).

Orlowska, Izabela. "The Legitimising Project: The Coronation Rite and the Written Word." Aethiopica 16 (2013): 74-101. https://doi.org/10.15460/aethiopica.16.1.700

Pankhurst, Sylvia. “Abyssinia's Ancient Freedom.” New Times and Ethiopia News (19 September 1936).

Paul, James C. N., and Christopher Clapham. Ethiopian Constitutional Development, Vol. 1. Addis Ababa: Haile Selassie I University, 1967.

Reid, Richard. Frontiers of Violence in North-East Africa: Genealogies of Conflict Since c.1800, Oxford: Oxford University Press, 2011.

Ricci, Lanfranco. "Letterature dell'Etiopia". In Storia delle letterature dell'Oriente, edited by Oscar Botto, 801-911. Milan: Casa Editrice Francesco Vallardi, 1969. 
Romero, Patricia W. E. Sylvia Pankhurst: Portrait of a Radical. New Haven/London: Yale University Press, 1987.

Rubenson, Sven, ed. Internal Rivalries and Foreign Threats, 1869-1879. Addis Ababa: Addis Ababa University Press, 2000.

Rubenson, Sven. "The Lion of the Tribe of Judah: Christian Symbol and/or Imperial Title." Journal of Ethiopian Studies 3, no. 2 (1965): 75-85.

Rubinkowska, Hanna. "The History that Never Was: Historiography by Haylä Śəllase I". In Studia Aethiopica: In Honour of Siegbert Uhlig on the Occasion of His $65^{\text {th }}$ Birthday, edited by Verena Boll, Denis Nosnitsin, Thomas Rave, Wolbert Smidt and Evgenia Sokolinskaia, 221-232. Wiesbaden: Harrassowitz Verlag, 2004.

Salvadore, Matteo. The African Prester John and the Birth of Ethiopian-European Relations, 14021555. London and New York: Routledge, 2016.

Shiferaw Bekele. "Reflections on the Power Elite of the Wärä Seh Mäsfenate (1786-1853)." Annales d'Ethiopie 15 (1990): 157-179. https://doi.org/10.3406/ethio.1990.951

Smidt, Wolbert G. C. "Glossary of Terms and Events of the Lïj Iyasu Period: Controversial and NonControversial Facts and Interpretations." In The Life and Times of Lï Iyasu of Ethiipia: New Insights, edited by Éloi Fiquet and Wolbert G. C. Smidt, 181-205. Berlin: Lit Verlag, 2014.

Sohier, Estelle. "Addis-Abeba et le Couronnement de Hāyla Sellāsē: Mise en Scène d'une Ville, Réinvention d'une Cérémonie." Annales d'Ethiopie 28 (2013): 177-202. https://doi.org/10.3406/ethio.2013.1534

Stylianoudi, Maria-Georgia. "Droit et Société en Éthiopie Médiévale: Ser'ata Mangest: Analyse Sémiotique d'un Texte Juridique Éthiopien”. PhD diss., Université de Lille III, 1984.

Taddesse Tamrat. Church and State in Ethiopia 1270-1527. New York: Oxford University Press, 1972.

Taddesse Tamrat. "Problems of Royal Succession in Fifteenth Century Ethiopia: A Presentation of the Documents." In Atti Del Convegno Internazionale di Studi Etiopici, 501-535. Rome: Accademia dei Lincei, 1974.

Toggia, Pietro. "History writing as a State Ideological Project in Ethiopia." African Identities 6, no. 4 (2008): 319-343. https://doi.org/10.1080/14725840802417869

Wärqenäh Đšate. “A Just Solution.” New Times and Ethiopia News (7 November 1936).

Waugh, Evelyn. Waugh in Abyssinia. London/NY/Toronto: Longmans Green \& co, 1936.

Winslow, Barbara. "The First White Rastafarian: Sylvia Pankhurst, Haile Selassie, and Ethiopia." In $A t$ Home and Abroad in the Empire: British Women Write the 1930s, edited by Robin Hackett, Freda Hauser and Gay Wachman, 171-186. Newark (NJ): University of Delaware Press, 2009.

\footnotetext{
${ }^{1}$ Budge, The Queen of Sheba, 147.

${ }^{2}$ Levine, Greater Ethiopia, 100-101.

${ }^{3}$ Ibid., 100.

${ }^{4}$ Marrassini, 'Kəbrä Nägäśt', 366.

${ }^{5}$ Kaplan, 'Solomonic Dynasty', 688.

${ }^{6}$ Ricci, 'Letterature dell'Etiopia', 815.

${ }^{7}$ Marrassini, 'Kəbrä Nägäśt', 366.

8 Taddesse Tamrat, 'Problems of Royal Succession'.

${ }^{9}$ Derat, Le Domaine, 28 (French: réserve dynastique). See pp. 24-29 for more information on the Amba Gäšen. All translations from French are mine.

10 Taddesse Tamrat, Church and State, $275 \mathrm{ff}$.

${ }^{11}$ Taddesse Tamrat, for example, describes how in the eleventh, twelfth and thirteenth century religious authorities repeatedly clashed with Ethiopian kings in the attempt to reform their marriage habits towards monogamy. Church and State, 116-118.

${ }^{12}$ Getachew Haile, 'Review of Bairu Tafla', 73.

${ }^{13}$ Hirsch and Fauvelle-Aymar, 'Aksum Après Aksum', 53.

${ }^{14}$ Ibid., 74.

15 Ibid., 92.

16 Ibid., 91.

${ }^{17}$ Ibid., 100.

18 Ibid., 75.
} 
${ }^{19}$ Crummey, 'Society and Ethnicity', 270.

${ }^{20}$ See Heran Sereke-Brhan, 'Like Adding'.

${ }^{21}$ Shiferaw Bekele, 'Reflections', 162 and 167.

${ }^{22}$ Fiquet, 'Understanding Lij Iyasu', 7. In this book chapter, Fiquet reconstructs the history of one of such regional families, the Memmedoch dynasty in Wällo, from whom Loj Iyasu would hail.

${ }^{23}$ Crummey, 'Imperial Legitimacy', 19.

${ }^{24}$ Orlowska, 'The Legitimising Project', 78.

${ }^{25}$ Crummey, 'Imperial Legitimacy' 34. Laj Iyasu was also related to the Solomonids via the female line (his mother was Mənilək's daughter), and his genealogical legitimacy was never put into discussion, not even in the 1916 coup that toppled him.

${ }^{26}$ Ibid., 33.

${ }^{27}$ Ibid., 31.

${ }^{28}$ Ibid., 20.

${ }^{29} \mathrm{Ibid}$.

${ }^{30}$ Ibid.

${ }^{31}$ Hirsch and Fauvelle-Aymar, 'Aksum Après Aksum', 101.

${ }^{32}$ Cited in Rubenson, Internal Rivalries, 112.

${ }^{33}$ Ibid., 111.

${ }^{34}$ Hirsch and Fauvelle-Aymar, 'Aksum Après Aksum', 101-102.

${ }^{35}$ Ibid., 65.

${ }^{36}$ Rubenson, 'The Lion of the Tribe'.

${ }^{37}$ British, Belgian, French, Italian, Egyptian, Japanese, Swiss, Swedish, Dutch, American, Greek, Polish and Turkish.

${ }^{38}$ See Kropp 'Notes' and Stylianoudi 'Droit et Société' for more information on the Sar'atä mängast.

${ }^{39}$ Haile Selassie, My Life and Ethiopia's Progress.

${ }^{40}$ Marcus, Haile Sellassie I, 111.

${ }^{41}$ Abuna Qerellos IV, who officiated the ceremony.

${ }^{42}$ Haile Selassie, My Life and Ethiopia's Progress.

${ }^{43}$ Ibid.

${ }^{44}$ Sohier, 'Addis-Abeba', 188.

${ }^{45}$ Ibid.

${ }^{46}$ Iyasu's own genealogical and marriage politics have only recently attracted scholarly attention. He skilfully played with his double ancestry. On his mother's side, he belonged to the Solomonic line, while his father's Muslim family had recently started claiming descent from the prophet Mohammed. Without heirs when he rose to power, Iyasu soon started an ambitious marriage policy, and married into Christian and Muslim families from various parts of the country. His polygamy was not rejected by any of his allies, be they Christian or Muslim. Just like the Christian Ethiopian emperors of the past negotiated with European powers mobilising their shared Christianity, Iyasu attempted to forge alliances with the Ottomans and with Somali leaders citing his father's ancestry. It was not uncommon for a ruler to claim descent not only from the Solomonic lineage, but also from locally influential lineages. In Iyasu's case 'it was new that such a claim included a prominent Muslim lineage. Thus [...] Lïj Iyasu showed a new approach, based on the ancient structures of genealogical politics' (Smidt, 'Glossary', 190).

${ }^{47}$ Rubinowska, 'The History That Never Was', 224-226.

${ }^{48}$ Sohier, 'Addis-Abeba', 181.

${ }^{49}$ De Lorenzi, Guardians of the Tradition, 23.

${ }^{50}$ Toggia, 'History Writing', 328.

${ }^{51}$ The full title is Wazema: Bämagastu YäItyopyan Nägästat Yätarik Bäal Lämakbär ('Eve: To Celebrate the History of Ethiopian Kings on the Morrow'). Bahru Zewde, Pioneers, 150-151 discusses the allegations that what Həruy published in his name was actually the unpublished manuscript on Ethiopian history written by Aläqa Tayyä Gäbrä-Maryam before his death in 1924.

${ }^{52}$ Bahru Zewde, Pioneers, 149-50.

${ }^{53}$ Bahru Zewde, Pioneers, 149.

${ }^{54}$ Ancel and Smidt, 'Legitimization of a Pretender', 206.

${ }^{55}$ Ibid., 205

${ }^{56}$ Ibid., 223.

${ }^{57}$ Ayele Bekerie, 'The Ethiopian Millennium', 24.

${ }^{58}$ Reid, Frontiers of Violence, 242.

${ }^{59}$ Banerjee, The Mortal God.

${ }^{60}$ Cited in Eadie, An Amharic Reader, 203.

${ }^{61}$ Cited in Bahru Zewde, Society, State and History, 204. 
${ }^{62}$ Cited in Molvaer, Black Lions, 56.

${ }^{63}$ Bahru Zewde, Society, State and History, 206-207.

${ }^{64}$ Key terms in the Amharic original: təwuld (offspring, generation), zär (seed, race), täyadäzo (being connected, rendered as sans interruption in the official French translation), nägäd (lineage, tribe, clan, descent group, rendered as dynastie in the official French translation). Note that the French translation, which was published alongside the Amharic text for the benefit of foreigners, is much stronger than the Amharic original, and explicitly conveys the notion of the 'uninterrupted dynasty'.

${ }^{65}$ Constitution d'Ethiopie/YäItyopya Həgä Mängəst, 7. My translation.

${ }^{66}$ For a study on Ethiopia's constitutional development, including the influence of the Meiji model on the 1931 constitution, see Paul and Clapham, Ethiopian Constitutional Development.

${ }^{67}$ Bahru Zewde, Society, State and History, 208.

${ }^{68}$ Ibid.

${ }^{69}$ Clarke, Alliance of the Colored People, 45.

${ }^{70}$ Bahru Zewde, Pioneers, 4.

${ }^{71}$ Bahru Zewde, Society, State and History 208-209.

${ }^{72}$ Salvadore, The African Prester John, 54.

${ }^{73}$ Ibid., 60.

${ }^{74}$ Ibid.

${ }^{75}$ Belcher, Abyssinia's Samuel Johnson, 24.

${ }^{76}$ Ibid., 16.

${ }^{77}$ Waugh, Waugh in Abyssinia, 35.

${ }^{78}$ Romero, E. Sylvia Pankhurst, 227.

${ }^{79}$ Napier, 'The Glory of Ethiopia'.

${ }^{80}$ Pankhurst, 'Abyssinia's Ancient Freedom'.

${ }^{81}$ Carnochan, Golden Legends, 93 and 95.

${ }^{82}$ Napier, Untitled.

${ }^{83}$ Romero, E. Sylvia Pankhurst, 227.

${ }^{84}$ Winslow, 'The First White Rastafarian', 189.

${ }^{85}$ Bahru Zewde, Pioneers, 120-137.

${ }^{86}$ Ibid., 206-207.

${ }^{87}$ Meseret Chekol Reta, The Quest, 71.

${ }^{88}$ Wärqenäh Әšate. 'A Just Solution'.

${ }^{89}$ Garvey, 'The Failure', 8-9.

${ }^{90}$ Fikru Negash Gebrekidan 2005, Bond Without Blood, 103.

${ }^{91}$ Garvey, 'The Failure', 8-9.

${ }^{92}$ Fikru Negash Gebrekidan 2005, Bond Without Blood, 109.

${ }^{93}$ Asafa Jalata, 'Being in and out of Africa', 189.

${ }^{94}$ Ibid. 